\title{
THE FAMILY OONOPIDAE (ARANEAE) IN FLORIDA*
}

\author{
By Arthur M. Chickering \\ Museum of Comparative Zoology
}

During my study of the family Oonopidae (Araneae) in Central America and the West Indies I have also become interested in this family as it exists in the State of Florida. In February, March and April, 1968, I had an opportunity to collect spiders in Florida as a part of my study of this group of animals with the support of the National Science Foundation Grant No. GB-5013. In addition to my own collection I have had helpful loans from the American Museum of Natural History and the University of Florida in Gainesville. Dr. W. J. Gertsch has also made it possible for me to examine the types of Ischnothyreus barrowsi Chamberlin and Ivie, 1935 and Stenoonops minutus C. and I., 1935, now being placed on semipermanent loan from the University of $\mathrm{Utah}$ to the American Museum of Natural History. Oonopidae from Florida and the West Indies now a part of the collections in the Museum of Comparative Zoology have also been very helpful in this study.

As usual, my entire collection of this family will be deposited in the Museum of Comparative Zoology. All types described from specimens on loan from the American Museum of Natural History will be deposited in that institution.

My appreciation and gratitude are again expressed for the continued aid and encouragement in the pursuit of my studies extended by the staff of the Museum of Comparative Zoology. My thanks are also extended to Dr. W. J. Gertsch, recently retired from the staff of the American Museum of Natural History and to Dr. Howard V. Weems, Jr., Florida Department of Agriculture, Gainesville, Florida, for the loan of very helpful collections. Grants GB-1801 and GB-5013 from the National Science Foundation have made it possible for me to continue my studies in the Museum of Comparative Zoology and on several collecting expeditions for nearly six years.

As a result of my study of the Oonopidae of Florida as indicated above I have been able to identify seven different genera. Among these I have been obliged to recognize five different species of the

*Manuscript received by the editor February 13, 1969

Published with the aid of a grant from the Museum of Comparative Zoology. 
genus Opopaea. It seems highly probable that diligent collecting in the habitats preferred by members of this family will yield additional genera and species not yet recorded in the state.

Key to the known genera of Oonopidae in Florida

I a. Genera with dorsal abdominal scutum (Ischnothyreus, Opopaea, Triaeris

\section{2}

Ib. Genera without a dorsal abdominal scutum (Heteroonops, Oonops, Orchestina, Stenoonops)

2a. Abdomen with dorsal and ventral scuta strongly chitinized and covering nearly the entire abdominal surface ........ Opopaea, p.

2b. Abdomen with scuta covering only a relatively small portion of the abdominal surface and not so strongly chitinized

(Ischnothyreus, Triaeris) 3

3a. ALE nearly contiguous to one another; PME contiguous to one another and to PLE; males with dark brown palps and a basal hook on the cheliceral fang

Ischnothyreus, p.

3b. ALE fairly well separated; PME contiguous but more or less well separated from PLE Triaeris, $\mathrm{p}$.

4a. PME moved far forward between ALE thus making an anterior row of four eyes Orchestina, p.

4b. PME not moved forward as given above; forming a somewhat recurved row with PLE .... (Heteroonops, Oonops, Stenoonops) 5

5a. Legs without conspicuous spines; venter of abdomen with a moderately well outlined epigastric scutum and with a narrow ventral scutum just posterior to the genital groove

Stenoonops, p.

5b. Legs with more or less conspicuous spines; venter of abdomen with weakly outlined scuta ............... (Oonops, Heteroonops) 6

6a. Palpal patella with a conspicuous prolateral bulge bearing robust spines; palpal femur and tibia also with conspicuous spines (Figs. 29-3I) Heteroonops, p.

6b. Palpal patella without notable distortion; palpal segments without conspicuous spines Oonops, p.

\section{Species with DORSAL abDominal SCUTUM}

\section{Genus Ischnothyreus Simon, I 893}

$$
\text { Ischnothyreus peltifer (Simon) }
$$

Ischnaspis peltifer Simon, 1891: 562. The female holotype from St. Vincent, B. W. I. is in the British Museum (Natural History), examined.

Ischnothyreus peltifer Simon, 1893: 298; (not the male p. 299 fig. 264). Petrunkevitch, 1911：127；1928：88；1929：66； Bryant, 1940：266; Roewer, 1942: 287; Chickering, 1951: 219; 1968: 80; Bonnet, 1957: 2309. 
Ischnothyreus barrowsi Chamberlin and Ivie, 1935: 9, fig. 7. The female holotype from Marco Island, Florida has been in the University of Utah but is now being placed in the American Museum of Natural History on semipermanent loan, examined. New Synonymy.

Dysderina antillana Bryant, 1942: 234; 1948: 340 . The female holotype from the Virgin Islands is in the Museum of Comparative Zoology, examined.

As I have shown in a recent publication (I968), this species is now well known from Costa Rica, Panama, many of the West Indies and now, also the State of Florida. I am, however, sceptical about its reported distribution in extensive areas of Asia and Africa. During my period of field work in Florida in the month of March ( I968) I collected a few specimens of both sexes in avocado groves in the vicinity of Homestead. Further careful collecting will probably show that the species is well distributed through at least the southern parts of the state.

\section{Genus Opopaea Simon, I89r}

There is considerable confusion in the literature regarding the characters used for separating the genus Opopaea from the genus Gamasomorpha. I am not at present prepared to attempt a clarification of this confusion and in view of this fact I am placing Gamasomorpha floridana Banks along with four other species in the genus
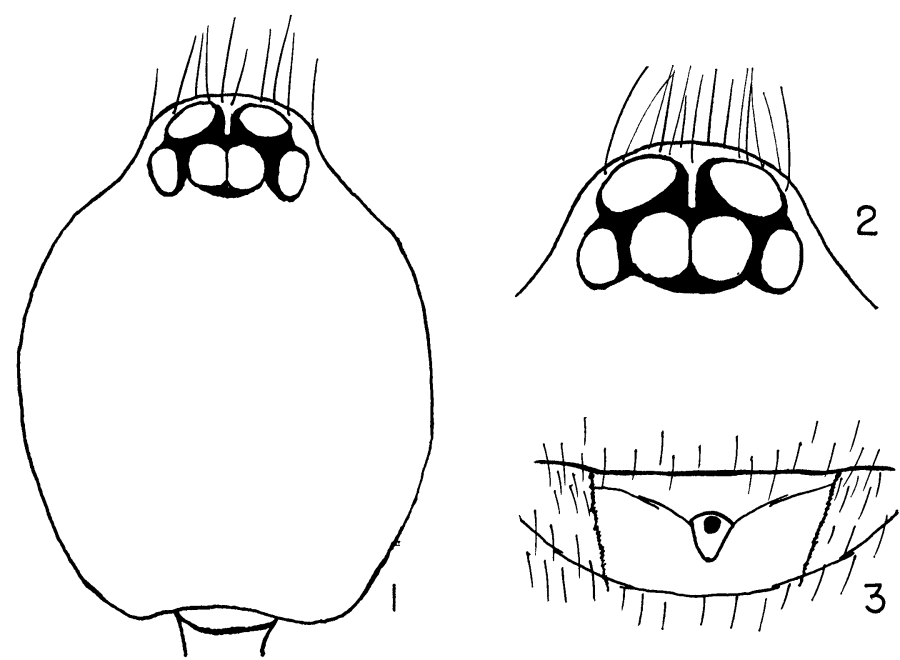

Figures 1-3. Opopaea bandina sp. nov. Fig. 1. Carapace from above. Fig. 2. Eyes from above. Fig. 3. Epigynal area from below. 
Opopaea. This decision appears to be in accord with the treatment given several species by Petrunkevitch (1929), Gertsch (1936), Bryant (1940), Chickering (195I), and Sumon (in part, 1965).

Key to the known males of Opopaea in Florida

Ia. Species with palpal patella greatly inflated as shown in Figures 5-8

O. brasima, $\mathrm{p}$.

Ib. Species with palpal patella not greatly inflated

(O. calona, O. lutzi) 2

2a. Species with palpal tarsus terminating in a pair of long, slender processes (Embolus and conductor)

O. lutzi, p.

2b. Species with palpal tarsus terminating in a pair of short processes turned at right angles O. calona, p.

No satisfactory key has yet been devised to aid in the separation of the five known kinds of females from Florida.

\section{Opopaea bandina sp. nov.}

Figures I-3

Holotype. The female holotype is from Pinellas Co., Largo, Florida, Nov., 1964. Collected by Mrs. Lorna R. Levi. The name of the species is an arbitrary combination of letters.

Description. Total length exclusive of the somewhat extended spinnerets $1.58 \mathrm{~mm}$; including the spinnerets total length is nearly I.67 mm. Carapace $0.56 \mathrm{~mm}$ long; $0.44 \mathrm{~mm}$ wide opposite second coxae where it is widest; about $0.20 \mathrm{~mm}$ tall; gently raised just behind PME and then nearly level along midline to beginning of steep posterior declivity opposite interval between third and fourth coxae; very finely rugulose as usual along lateral surfaces; with numerous short hairs. Eyes: six as usual in a compact group; posterior row only moderately recurved. Ratio of eyes ALE: PME: terior row only moderately recurved. Ratio of eyes ALE : PME : PLE $=$ I2 : IO : 9.5. ALE separated from one another by about one fourth of their diameter (some irregularities in outlines noted); separated from PME and PLE by broad lines. PME contiguous as usual and separated from PLE by a broad line. With a moderate amount of black pigment in ocular area. Height of clypeus nearly equal to radius of ALE. Folded fragile legs make it difficult to observe closely the chelicerae, maxillae, palps and lip but apparently all are typical of females of the genus. Sternum: quite typical of the genus; longer than wide in ratio of about $4: 3$; with marginal lobes and grooves moderately developed; posterior end squarely truncate, viewed directly from below; extended between bases of 
fourth coxae which are separated by nearly twice their width. Legs: 4I-23 in order of length; no spines observed; only hairs, bristles and trichobothria. Abdomen: typical of the genus in general; dorsal scutum covers about ten-elevenths of dorsal surface; ventral and epigastric scuta cover nearly four-fifths of ventral surface; with rather wide lateral surfaces bare of scuta. Epigynal area obscurely distinctive (Fig. 3). Color in alcohol: quite typical of the genus. This species appears to be more or less closely related to Opopaea recondita Chickering.

Records. One female paratype taken with the holotype. One female assigned to this species is from "Alachua Co., Florida, Science Hall bookcase"; no further data given but assumed to have been taken at the University of Florida, Gainesville. Two females from Edgewater, Florida, February r939 (C. A. Frost) filed in Museum of Comparative Zoology as Gamasomorpha floridana Banks. Four females on loan from the American Museum of Natural History from the following localities: Lake Placid, Archbold Research Station, Nov. 23, I952; December 8, 1959 and October I, I962 together with De Soto City, October 5, I962 (all four just noted collected by A. M. Nadler).

\section{Opopaea brasima sp. nov.}

Figures 4-IO

Holotype. The male holotype is from Kendall, Florida, Mar. 1953; collected by A. M. Nadler. The name of the species is an arbitrary combination of letters. The holotype will be deposited in the American Museum of Natural History, New York City.

Description. Total length I. $3 \mathrm{~mm}$ Carapace $0.55 \mathrm{~mm}$ long; 0.44 $\mathrm{mm}$ wide opposite second coxae where it is widest; nearly $0.22 \mathrm{~mm}$ tall; nearly flat along midline from slightly behind PME to beginning of steep posterior declivity; posterior border recurved; lateral and posterior surfaces finely rugulose; with numerous black hairs. Eyes: six as usual in a compact group; viewed from above, posterior row only gently recurved. Ratio of eyes ALE : PME : PLE = I3 : II : IO. ALE separated from one another by nearly half their radius. PME contiguous to one another and separated from PLE by a line. Height of clypeus nearly equal to two-thirds of the diameter of ALE. Chelicerae, maxillae and lip apparently quite typical of the genus. Sternum: moderately convex and moderately lobed along lateral margins; with marginal bristles curved medially; only a little longer than wide; nearly squarely terminated between bases of fourth coxae which are separated by about their width. Legs: 

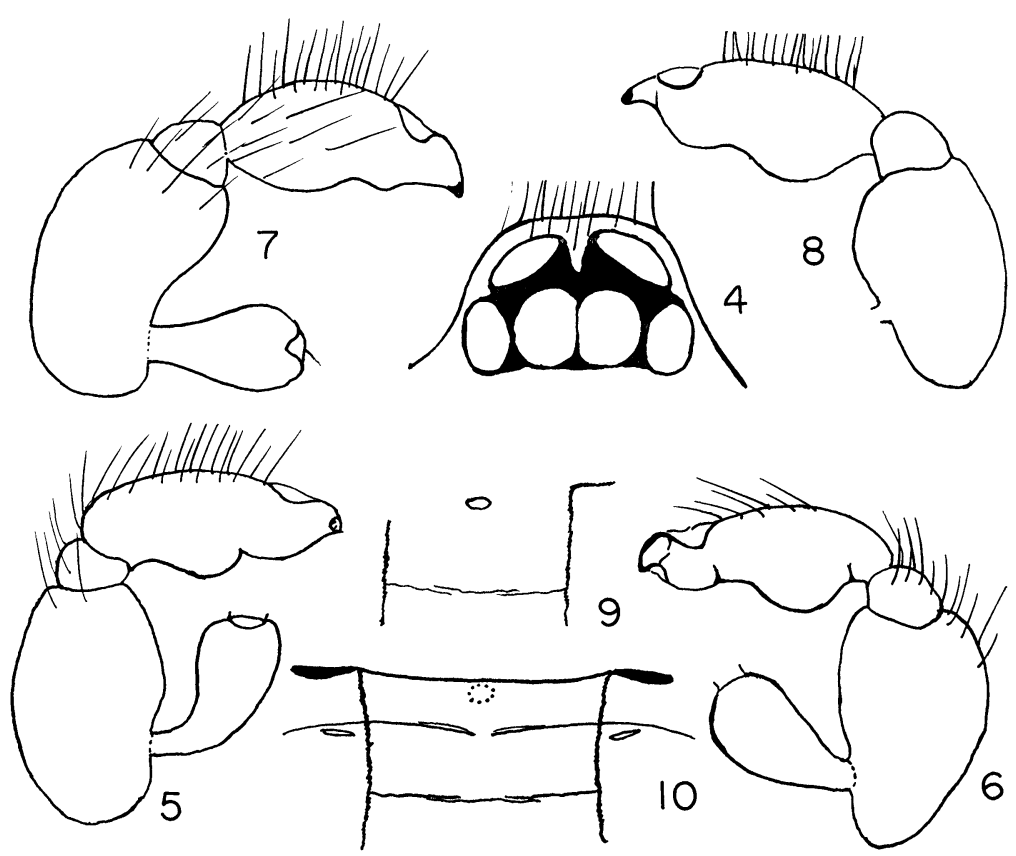

Figures 4-10. Opopaea brasima sp. nov. Fig. 4. Eyes of holotype from above. Figs. 5-6. Left palp of holotype; prolateral and retrolateral views, respectively. Fig. 7. Left palp of male from Homestead; prolateral view. Fig. 8. Left palp of male from Haines City; retrolateral view. Fig. 9. Genital area of male holotype. Fig. 10. Epigynal area of described female paratype.

4123 in order of length; no true spines observed; many hairs and spiniform bristles. Palp: essential features shown in Figures 5-8; femur short and moderately inflated; patella strongly inflated; tibia very short; tarsus with distinctive features obscure and difficult to observe clearly; a slight change of position greatly alters appearance. Abdomen: typically flattened; dorsal scutum covers entire dorsal area; ventral and epigastric scuta cover entire ventral surface back to bases of normal spinnerets; the expected sclerite at base of spinnerets shows dorsal to posterior border of ventral scutum; genital area very similar to that of Opopaea calona sp. nov. (Fig. 9). Color in alcohol: essentially as recorded for other species in the genus Opopaea.

Female paratype. Total length I. $67 \mathrm{~mm}$. Carapace $0.59 \mathrm{~mm}$ long; about $0.46 \mathrm{~mm}$ wide opposite posterior borders of second coxae; 
nearly $0.23 \mathrm{~mm}$ tall. Eyes: essentially like those of male holotype except that the posterior row appears to be straight or very slightly procurved, measured by posterior borders. Ratio of eyes ALE : PME : PLE = го : го : 9; PME plainly longer than wide (long diameters always used for measurements); posterior row occupies about three-fourths of width of carapace at that level. Chelicerae, maxillae, palps and lip all appear to be typical of females of the genus. Sternum and legs appear to be essentially like those of male holotype. Abdomen: scuta essentially as in male except that a larger area at posterior end of the abdomen is left uncovered on both dorsal and ventral sides. The epigynal area is very obscure but is, never-the-less, quite distinctive (Fig. IO). Color in alcohol: essentially as in male with minor differences.

Records. The described female paratype was taken $2 \mathrm{mi}$. southeast of Marathon, Florida, December I 5, 1962 (Wilton Ivie). Numerous males and females have been on loan from the American Museum of Natural History as follows: Punta Gorda, January 1946 (Stowell Rounds); Alachua Co., Science Hall, Dec. 6, I948; Key West, Dec. I950 (A. M. Nadler) ; 2-5 mi. so. of Florida City, April I, I957 (R. Forster and W. J. Gertsch) ; 2 mi. southeast of Marathon, Dec. I 5, I962 (Wilton Ivie). I collected this species at Haines City, Feb. 28 and at Homestead, March, I968. The male described as the allotype of Gamasomorpha floridana Banks by Miss Elizabeth Bryant apparently belongs in this species. Early in the study of this group of specimens three different species seemed to be present. Careful examination of all of them have finally convinced me that they all belong in a single species as presented here.

\section{Opopaea calona sp. nov.}

\section{Figures I I-I9}

Holotype. The male holotype is from Florida. The label reads: Science Hall, October I5, I947. Another vial on loan from the American Museum of Natural History states that Science Hall is in Alachua Co. It is assumed, therefore that this specimen was taken in Science Hall at the University of Florida in Gainesville. It will be deposited in the American Museum of Natural History, New York City. The holotype has the abdomen separated from the cephalothorax but is in good condition for description.

Description. Total length nearly $\mathrm{I} .54 \mathrm{~mm}$. Carapace $0.66 \mathrm{~mm}$ long; $0.49 \mathrm{~mm}$ wide opposite second coxae where it is widest; about $0.23 \mathrm{~mm}$ tall; raised somewhat just behind PME and then slightly arched to slightly raised portion just at beginning of steep posterior 
declivity; just beneath posterior border there is a strongly chitinized conical projection not seen in any other species studied (Fig. II); general form as in Figures I7-I8 of female; surface nearly smooth and shiny with no median thoracic pit or groove. Eyes: six in two rows and in a compact group as usual; posterior row rather strongly recurved (Figs. I2-I3) and occupies nearly three-fourths of width of carapace at that level. Ratio of eyes ALE : PME : PLE $=$ I2.5 : IO : I I. ALE separated from one another by nearly three-fourths of their diameter and only slightly separated from PME and PLE. PME contiguous for nearly their length and narrowly separated from PLE. Clypeus only slightly porrect; with height nearly equal to five-sixths of diameter of ALE. Chelicerae apparently as usual in the genus. Maxillae moderately convergent, slender and apparently without special modifications. Lip apparently as usual in the genus. Sternum: quite convex; nearly as wide as long; posterior end slightly bilobed and extended just to bases of fourth coxae which are separated by nearly twice their width; with a sparse supply of stiff bristles; only slightly lobed and grooved along margins. Legs: $4 \mathrm{I}=23$ in order of length; no true spines observed on legs or palps. Palp: general features shown in Figures I4-I 5 ; only tarsus inflated; features of tarsus appear to be unique since no structures like these closely adherent and so difficult to follow have been seen in collections available to me for study. Abdomen: dorsal scutum covers all of dorsal surface except a small area just above the anal tubercle; ventral and epigastric scuta cover all of venter except a narrow area just anterior to nearly semicircular sclerite at base of spinnerets; genital area as shown in Figure r6; dorsal and epigastric scuta nearly meet dorsal to base of pedicel but diverge posteriorly so that a lateral area of considerable size is left uncovered. Color in alcohol: carapace, sternum and scuta all a clear yellowish brown; legs yellowish; black pigment in ocular area essentially as shown in Figures 12-13; abdominal areas not covered by scuta a clear white.

Female paratype. I.61 mm. Carapace about $0.7 \mathrm{~mm}$ long; about $0.53 \mathrm{~mm}$ wide opposite second coxae where it is widest; about $0.3 \mathrm{~mm}$ tall; somewhat overlapped by anterior end of abdomen; otherwise essentially as in male (Figs. I7-18). Eyes essentially as in male. Chelicerae, maxillae and lip essentially as in male with minor differences. Sternum as in male. Second legs missing but apparently all legs essentially as in male. Female palp as usual in females of the genus. Abdomen: the three recognized scuta cover almost the entire abdominal surface with very little exposure of the uncovered white surface; the epigynal area appears to be more or less distinctive 


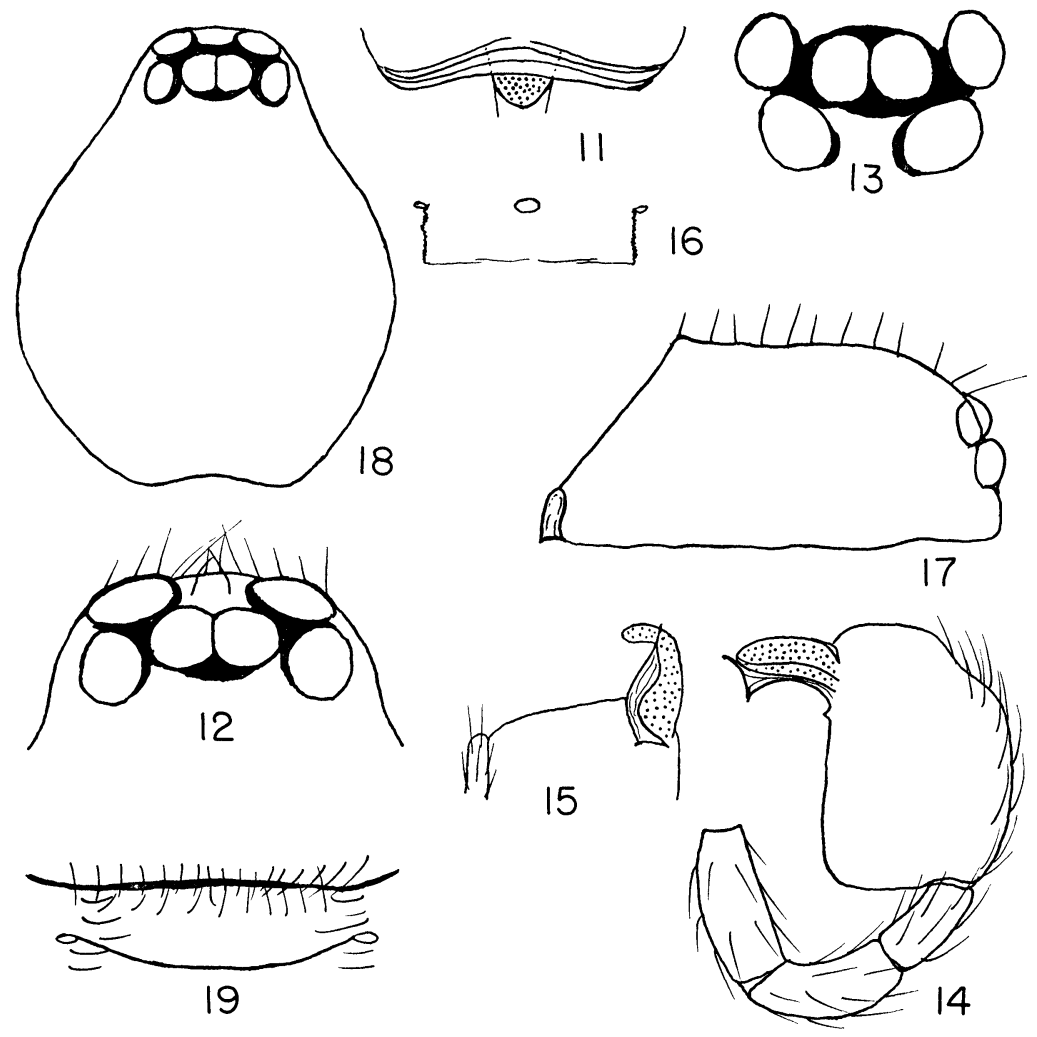

Figures 11-19. Opopaea calona sp. nov. Fig. 11. Posterior border of carapace from above; with conical extension of posterior border lying over the pedicel. Figs. 12-13. Eyes of male holotype from above and from in front, respectively. Fig. 14. Left male palp; retrolateral view. Fig 15. Tip of left male palpal tarsus; nearly ventral view. Fig. 16. Genital area of male holotype. Fig. 17. Carapace of described female paratype; right lateral view. Fig. 18. Carapace of female from above. Fig. 19. Epigynal area of female paratype from below. 
(Fig. I9) and seems to indicate a close relationship with species such as Opopaea lutzi Pet. where the male palp has no greatly inflated patella such as occurs in species like Opopaea timida Chick. and numerous others to be treated later.

Records. No male paratypes have been found in the collection. The female, regarded as the described female paratype of this species, is from Valparaiso, Florida, April 1946 (Edwards).

\section{Opopaea floridana (Banks)}

Figures 20-2 I

Gamasomorpha floridana Banks, 1896: 57. The female holotype from Punta Gorda, Florida is in the Museum of Comparative Zoology, examined. Banks, 1904: 122; 1910: 5; Petrunkevitch, 1911: 126; Roewer, 1942: 286; Bryant, 1945: 199, not the male described as the allotype; this specimen was misidentified and is now placed with Opopaea brasima sp. nov.; Comstock, 1948: 309; Bonnet, 1957: 1930.

Two specimens are in the type vial; one is somewhat injured with cephalothorax and abdomen detached; the other is in good condition and has been used in this study. As indicated above, I cannot accept the male described as the male of this species. Several features seem to me to separate it very definitely from Banks' species.

Female holotype. Total length $\mathrm{r} .85 \mathrm{~mm}$. Ratio of eyes ALE : PME : PLE $=$ nearly $7: 6: 5$. ALE separated from one another by a little more than their diameter (Fig. 20) ; separated from PME and PLE by a broad line. PME contiguous as usual and separated from PLE by nearly one half their width. The epigynal area (Fig. 2I) seems to indicate that this species is closely related to Opopaea lutzi Pet. I am inclined to the belief that when the male of this species is definitely identified it will be found to belong to the group in which the palpal patella is not greatly inflated nor with the palpal tibia so much diminished (Opopaea lutzi Pet. and Opopaea calona sp. nov.)

\section{Opopaea lutzi Petrunkevitch}

Figures 22-27

Opopaea lutzi Petrunkevitch, 1929: 61, figs. 42-50. The male holotype from Desecheo Island, Puerto Rico is probably in the American Museum of Natural History, New York City. Bryant, 1940: 267; Roewer, 1942: 288 ; Bonnet, 1958 : 3197.

In addition to the holotype male Dr. Petrunkevitch also had an immature specimen taken with the holotype and a male and two immature specimens from Dorado, Puerto Rico. Miss Bryant ( 1940) had both sexes from Cuba. The species is now believed to be widely distributed in Central America and the West Indies as I hope to 
show in a later paper on this genus. I now have on loan from the American Museum of Natural History two females from Florida; one is from Crandon Park, Dade Co., November 27, I952 (A. M. Nadler) and the other is from Kendall, Dade Co., November 26, I965 (A. M. Nadler). I have in my personal collection several specimens of both sexes from Homestead, Florida, March, I968. The species seemed to be abundant in leaf litter in avocado groves on West Mowry St; I also have both sexes taken from litter in an open field near the avocado groves just mentioned. Although the basic pattern of the parts associated with the epigynal area remain consistent the arrangement of the folds, grooves, etc. varies considerably among the specimens available for study.

\section{Genus Triaeris Simon, I89I}

\section{Triaeris stenaspis Simon}

Triaeris stenaspis Simon, 1891: 561. The type females from St. Vincent, B. W. I. are in the British Museum (Natural History). Simon, 1892: 443; 1893: 302; Petrunkevitch, 1911: 130; 1928: 88; Roewer, 1942: 290; Bryant, 1948: 342; Bonnet, 1959: 4684; Chickering, 1969 (in press).

Triaeris patellaris Bryant, 1940: 268. The type female from Cuba, W. I. is in the Museum of Comparative Zoology. Chickering, 1951: 243.

In a brief paper on the genus Triaeris in Central America and the West Indies now in press I have shown that $T$. stenaspis Simon is now known to be widely distributed in Costa Rica, Nicaragua, Panama and many of the West Indies with one record from Miami, Florida. I now believe that I have additional records from Fort Myers, January I934 (W. M. Barrows) and also from Miami, Brickell Hammock, November 30, r96r (F. M. Mead). The male is still unknown.

\section{Species without a DORSAL SCUTUM \\ Genus Heteroonops Dalmas, I9I6 Heteroonops spinimanus (Simon) \\ Figures 28-32}

Oonops spinomanus Simon, 1891: 563, fig. 6. The female holotype from St. Vincent, B. W. I. is in the British Museum (Natural History). Simon, 1893: 294; 1892: 445; Petrunkevitch, 1911: 128; 1929: 67, figs. 53-57; Gertsch, 1936: 8.

Heteroonops, spinimanus, - Dalmas, 1916: 203, 217; Bryant, 1940: 205; Roewer, 1942: 276; Bonnet, 1957: 2185.

Simon had only the female. Dr. Petrunkevitch had what he considered to be "several males and females" from Puerto Rico. Miss Bryant recorded the species from Cuba. Dr. Gertsch was the first to record it from Florida. The species is now believed to be widely 

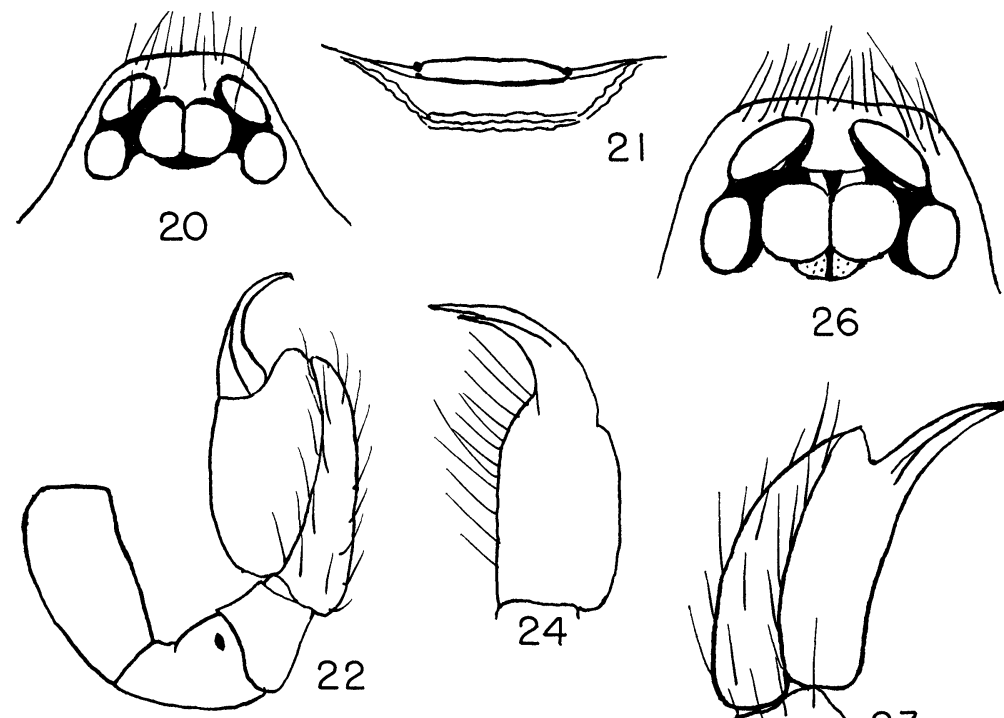

26
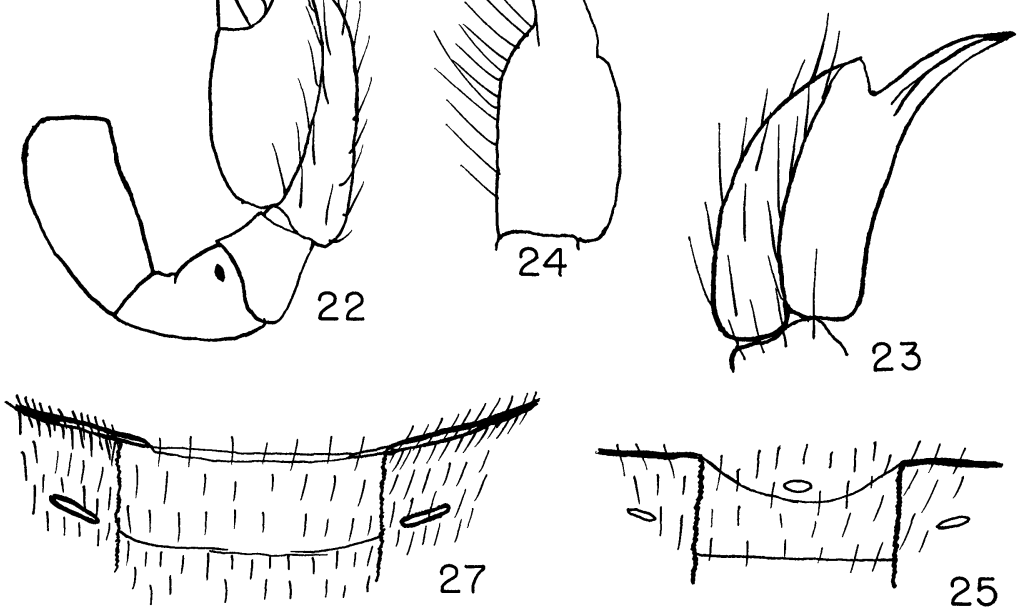

Figures 20-21. Opopaea floridana (Banks). Fig. 20. Eyes of female from above. Fig. 21. Epigynal area from below. Figures 22-27. Opopaea lutzi Petrunkevitch. Fig. 22. Left palp of male; retrolateral view. Figs. 23-24. Left male palpal tarsus; prolateral and nearly ventral views, respectively. Fig. 25. Genital area of male from below. Fig. 26. Eyes of female from above. Fig. 27. Epigynal area of female from below.

distributed in the northern parts of South America, at least in the southern parts of Central America, in many of the West Indies and at least in Florida in the United States. I am not certain that the species should be separated from the genus Oonops but for the present I am leaving it where Dalmas placed it.

I am also uncertain concerning the male of the species described by Dr. Petrunkevitch. I have not yet been able to identify the male with any degree of certainty among the numerous species of Oonops now awaiting final treatment. The eyes of the female are represented in Figure 28. There is a moderately well outlined epigastric 
scutum and a narrow ventral scutum. The epigynal area is quite distinctive (Fig. 32) with some variation in its appearance among numerous available specimens. The palp of the female is quite distinctive in respect to the shape of the patella and the conspicuous spination on several segments (Figs. 29-3 I ).

In a collection of Oonopidae from the American Museum of Natural History I have found females from the following localities in Florida: Royal Palm Park, Feb. 26, I936; Leesburg, Lake Co., March I-I I, I954 (M. Stratham); Lake Placid, Archbold Biol. Sta., Oct. I, I962 (A. M. Nadler) ; Ochopee, Everglades, December 27, I963 (Jean and Wilton Ivie). Dr. Gertsch (1936) reported the species from Newnan's Lake, near Gainesville and also stated that Dr. H. K. Wallace had females from localities in Alachua Co. In my personal collection from Florida in I968 I have females from Homestead, March; Everglades National Park, March; Tallahassee, Tall Timbers Research Station, April.

\section{Genus Oonops Templeton, I834 Oonops floridanus (Chamberlin and Ivie)}

Figures 33-34

Oonopinus floridanus Chamberlin and Ivie, 1935: 9, figs. 8-9. The holotype male and female paratype have been in the Museum of the University of Utah, Salt Lake City but are now being transferred to the American Museum of Natural History, New York City. Roewer, 1942: 276.

Oonops floridanus, - Gertsch, 1936: 9; Bonnet, 1958: 3190.

Dr. Gertsch correctly recognized that this species belongs in the genus Oonops. The original description stated that there were no spines on the legs; actually there are many long slender, more or less transparent spines somewhat difficult to observe.

I did not collect this species during my period of field work in Florida in 1968 but I have had numerous specimens of both sexes on loan from the American Museum of Natural History and the University of Florida collected by H. A. Denmark, R. M. Baranowski, Drs. W. J. Gertsch and R. R. Forster, Dr. Wilton Ivie and Dr. F. E. Lutz. These collections have been made in numerous localities throughout the State of Florida and seem to indicate that this species is one of the most abundant in the family. Figure 33 represents the eyes of the male as seen from above; Figure 34 represents the left palpal patella, tibia and tarsus of a male as seen in retrolateral view. The epigynal area of females is extremely obscure and appears to be quite variable in appearance and for this reason no figure of this region has been prepared. 

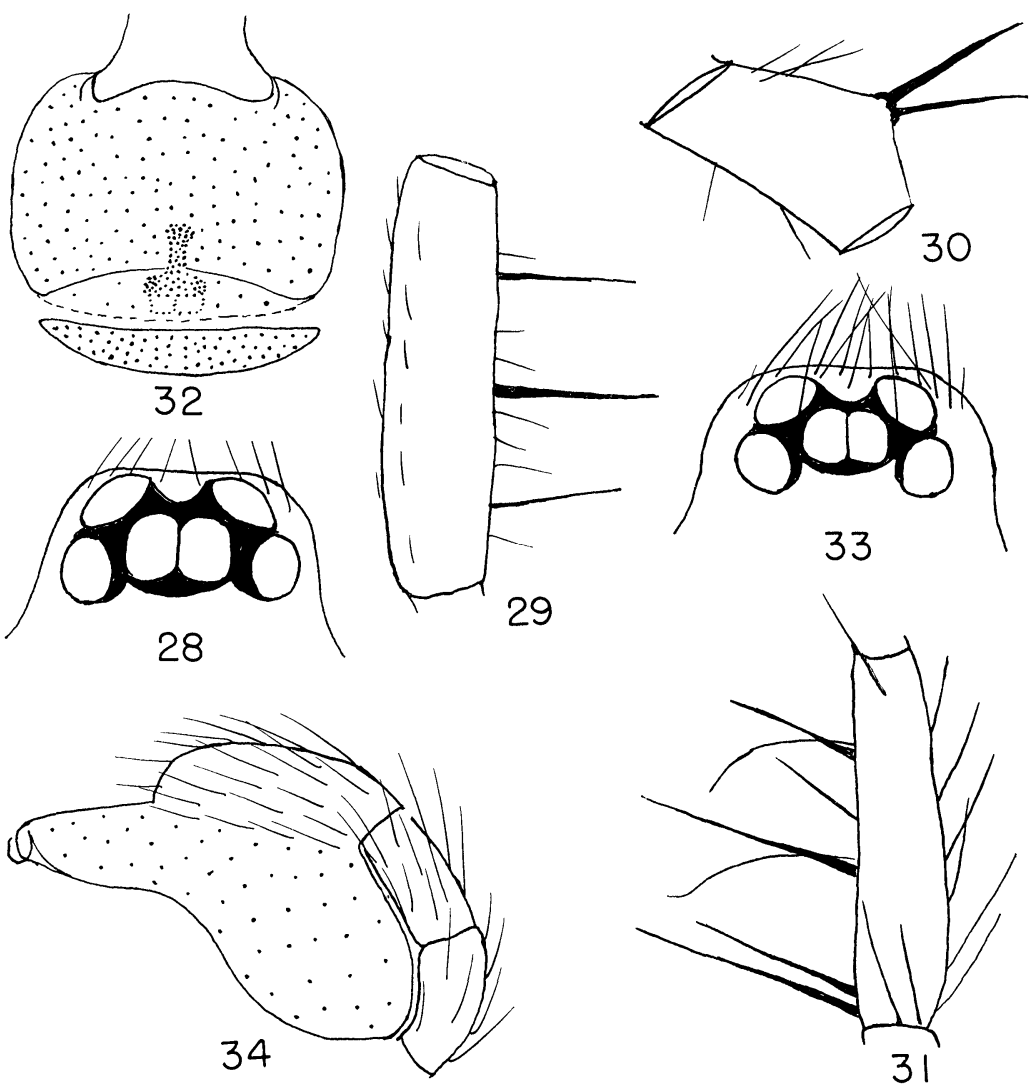

Figures 28-32. Heteroonops spinimanus (Simon). Fig. 28. Eyes of female from above. Fig. 29. Right palpal femur; retrolateral view. Fig. 30. Right palpal patella; dorsal view. Fig. 31. Right palpal tibia; dorso-prolateral view. Fig. 32. Epigynal area of female. Figures 33-34. Oonops floridanus (C. and I.). Fig. 33. Eyes of male from above. Fig. 34: Left palpal patella, tibia and tarsus; retrolateral view. 
Several immature specimens of Oonops are in the collections but I have been unable to place them with any certainty.

Genus Orchestina Simon, I882

Orchestina nadleri sp. nov.

Figures 35-39

Holotype. The male holotype is from Key West, Florida, December 3I, I950 (A. M. Nadler). The species is named after the collector.

Description. Total length about $1.0 \mathrm{~mm}$ (body bent and very fragile). Carapace $0.46 \mathrm{~mm}$ long; about $0.33 \mathrm{~mm}$ wide opposite interval between second and third coxae where it is widest; about $0.24 \mathrm{~mm}$ tall opposite third coxae where it is tallest (Fig. 36) ; surface smooth with few hairs. Eyes: six as usual; with PME moved forward to make a row of four with ALE (Fig. 35); four posterior eyes in a strongly recurved row occupying about seven-ninths of width of carapace at that level. Ratio of eyes ALE : PME : PLE = about 8.5 : I2 : Io (long diameters always used for measurements). ALE separated from one another by slightly more than twice their diameter; well separated from PME and nearly contiguous to PLE. PME contiguous for nearly one-third of their circumference and separated from PLE by nearly their width. Clypeus somewhat porrect and with height a little more than width of PME. Chelicerae vertical and apparently without special modifications. Maxillae convergent; nearly meeting in front of lip which is somewhat diamond-shaped with posterior angle fitting into a median sternal groove not seen elsewhere. Sternum: scutiform; somewhat convex; without marginal lobes; bluntly terminated opposite bases of fourth coxae which are well separated. Legs : $4 \mathrm{I}=23$ in order of length; fourth coxae somewhat enlarged; fourth femora elongated and enlarged as usual in the genus; probably lacking true spines but with numerous hairs, bristles and trichobothria. Palp: parts so fragile that no attempt has been made to remove it for the usual more complete examination. Figure 37 shows the essential features of the left palpal tibia and tarsus in retrolateral view. Abdomen: as usual in the genus. Color in alcohol: cephalothorax, legs and mouth parts light yellowish; abdomen almost white except for an area around the posterior end which appears light purplish gray.

Female paratype. Total length about $\mathrm{I} .43 \mathrm{~mm}$. Carapace about $0.55 \mathrm{~mm}$ long; about $0.44 \mathrm{~mm}$ wide; dorsal surface injured thus preventing determination of height. Eyes, mouth parts, sternum and legs all appear essentially as in male with minor variations. Ab- 


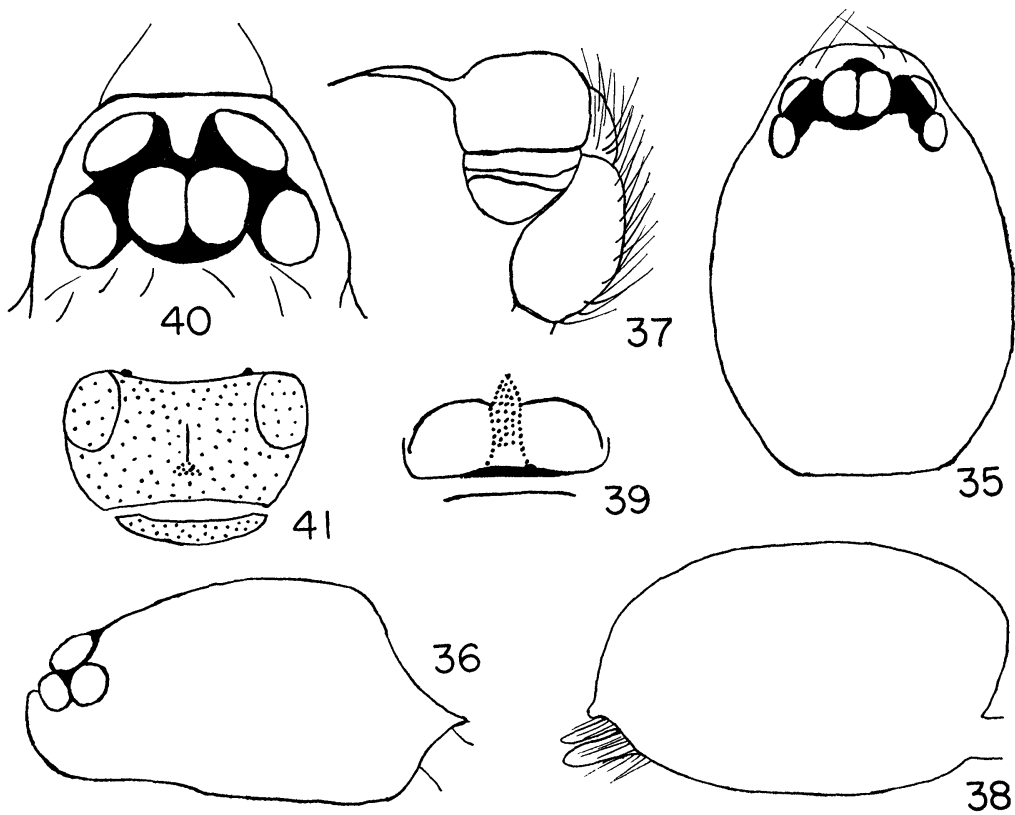

Figures 35-39. Orchestina nadleri sp. nov. Fig. 35. Carapace of male holotype from above. Fig. 36. Carapace of male; left lateral view. Fig. 37. Left male palpal tibia and tarsus; retrolateral view. Fig. 38. Abdomen of female paratype; right lateral view. Fig. 39. Epigynal area of female paratype. Figures 40-41. Stenoonops minutus C. and I. Fig. 40. Eyes of female from above. Fig. 41. Epigynal area of female.

domen: general form essentially as shown in Figure 38; the epigynal area is only very dimly outlined but it seems to be distinctive (Fig. 39).

Records. There are no male paratypes. The described female paratype is from Key West, Florida, December 29, I950 (A. M. Nadler). A second female belonging to the genus Orchestina is in very poor condition. From what can be observed, however, I have tentatively concluded that it represents another species and this suggests that more thorough collecting in the State of Florida would be likely to yield additional interesting species. Two immature specimens from Torreya State Park, Liberty Co., Florida, on loan from the University of Florida, seem to be close to the genus Orchestina but their condition precludes precise treatment. 
The male holotype had apparently been selected and named by Dr. W. J. Gertsch for description but was never completed. I have merely accepted the specimens and proceeded with the description as given above.

Genus Stenoonops Simon, I891

Stenoonops minutus Chamberlin and Ivie

Figures 40-4I

Stenoonops minutus Chamberlin and Ivie, 1935: 8, figs. 1-2, 14. The male holotype from Tampa, Florida, August 26, 1933, formerly in the $\mathrm{Mu}$ seum of the University of Utah is now being transferred to the American Museum of Natural History, New York City, examined. Roewer, 1942: 280; Bonnet, 1958 : 4156.

The authors of this species had only the male holotype. A female from Newnan's Lake, Gainesville, Fla., March 23, I957 (Gertsch and Forster) has been selected for description as follows:

Female. Total length $1.43 \mathrm{~mm}$ exclusive of the somewhat extended spinnerets; including the spinnerets total length is $1.54 \mathrm{~mm}$. Carapace about $0.6 \mathrm{~mm}$ long; about $0.43 \mathrm{~mm}$ wide opposite second coxae where it is widest; about $0.22 \mathrm{~mm}$ tall; very slightly arched along midline from PME to beginning of moderately steep posterior declivity nearly opposite third coxae; with few short hairs; lateral surfaces very finely granulate; no median thoracic pit or groove observed. Eyes: six as usual in two rows; viewed from above, posterior row recurved (Fig. 40). Ratio of eyes ALE : PME : PLE = nearly $7: 6: 5$. ALE separated from one another by a little more than their radius; separated from PLE by nearly their radius and from PME by a broad line; PME contiguous for about one fourth of their circumference and separated from PLE by a broad line. Height of clypeus nearly equal to the radius of ALE. Some irregularities noted in shapes of eyes; long diameters always used for measurements. Chelicerae, maxillae and lip all as usual in the genus as far as observed. Sternum: convex; about seven-ninths as wide as long; widest just behind second coxae; plainly lobed and grooved along margins as usual in the genus; margins with curved black hairs; posterior end rounded and terminated just opposite bases of fourth coxae which are separated by nearly six-fifths of their width. Legs: $4 \mathrm{I}=23$ in order of length; only slight differences in lengths; no true spines observed; trichobothria present but number and placement undetermined. Abdomen: ovoid as usual in the genus; epigastric and ventral scuta together with epigynal area weakly outlined (Fig. 4r); spinnerets as usual in the genus. Color in alcohol: as usual in the genus with minor variations; carapace and sternum somewhat lighter than 
in S. nitens Bryant from St. Croix, U. S. Virgin Islands but otherwise very similar.

Records. On loan from the American Museum of Natural History: two males and five females from Newnan's Lake, Gainesville, Florida, March 28, I957 (Gertsch and Forster); two males from Torreya State Park, Florida, April 4, 1957 (Gertsch and Forster); one female from Myakka River State Park, December 26, 1963 (Jean and Wilton Ivie). One male in the Museum of Comparative Zoology from Welaka, Florida, May 9, I949 (A Van Felt) probably belongs here but both palps are missing. Another female from Dunedin, Florida, I927 (W. S. Blatchley) filed in the Museum of Comparative Zoology as Gamasomorpha floridana Banks is also placed here with some uncertainty because of its obscure features.

BANKS, NATHAN

\section{BiBLIOGRAPHY}

1896. New North American Spiders and Mites. Trans. Amer. Ent. Soc., 23 : 57-77.

1904. The Arachnida of Florida. Proc. Acad. Nat. Sci., Phila. 56: 120-147, pls. 7-8.

1910. Catalogue of Nearctic Spiders. Bull. U.S. Nat. Mus. 72: 180.

Bonnet, Pierre

1955-1959. Bibliographia Araneorum. Toulouse. 2(1-5).

Bryant, ElizaBETH

1940. Cuban Spiders in the Museum of Comparative Zoology, Bull. Mus. Comp. Zool., $86(7): 249-532,22$ pls.

1942. Notes on the Spiders of the Virgin Islands. Bull. Mus. Comp. Zool., $89(7)$ : 317-363, 3 pls.

1945. Notes on Some Florida Spiders. Trans. Connecticut Acad. Arts and Sci., 36: 199-213.

1948. The Spiders of Hispaniola. Bull. Mus. Comp. Zool., 100: 331447,12 pls.

Chamberlin, R. V. and Wilton IVie

1935. Miscellaneus New American Spiders. Bull. Univ. of Utah, 26(4) : 1-79.

Chickering, A. M.

1951. The Oonopidae of Panama. Bull. Mus. Comp. Zool., 106(5): 207-245.

1968. The Genus Ischnothyreus (Araneae, Oonopidae) in Central America and the West Indies. Psyche, 75(1): 77-86.

1969. The Genus Triaeris Simon (Araneae, Oonopidae) in Central America and the West Indies. Psyche 75: 351-359.

Comstock, J. H.

1948. The Spider Book (revised by W. J. Gertsch). Comstock Publishing Associates, Ithaca, N. Y. 
Dalmas, Compte de

1916. Revision du Genre Orchestina E. Simon. Ann. Soc. Entom. France, 85: 203-258, 30 figs.

Gertsch, W. J.

1936. Further Diagnoses of New American Spiders. Amer. Mus. Novitates, No. 852. The American Museum of Natural History, New York City, pp. 1-27, 4 pls.

Petrunkevitch, Alexander

1911. A synonymic index-catalogue of spiders of North, Central, South America, etc. Bull. Amer. Mus. Natur. Hist., 29: 1-809.

1928. Systema Araneorum. Trans. Connecticut Acad. Arts and Sci., 29: 1-270.

1929. The Spiders of Porto Rico. Pt. 1. Trans. Connecticut Acad. Arts and Sci. 30:7-158, 150 figs.

ROEWER, C. Fr.

1942. Katalog der Araneae. 1: 1-1040.

SIMON, E.

1882. Études Arachnologiques, 13e mémoire. Descriptions d'espèces et de genre nouveau de la famille des Dysderidae. Ann. Soc. Ent. France, sér. (6) 2: 201-240.

1891. On the spiders of the island of St. Vincent. Pt. 1. Proc. Zool. Soc. of London, Nov. 17, 1891 : 549-575.

1892. Voyage de M. E. Simon au Venezuela. Ann. Soc. Entom. France, 61: 423-462, $1 \mathrm{pl}$.

1892-1893. Histoire naturelle des Araignées. Deuxième Edition. 2 vols. Librarie Encyclopedique de Roret, Paris.

TEMPleton, R.

1835. On the spiders of the Genus Dysdera Latr. with the description of a new allied genus. Zool. Jour., 5: 400-408, 1 pl. 

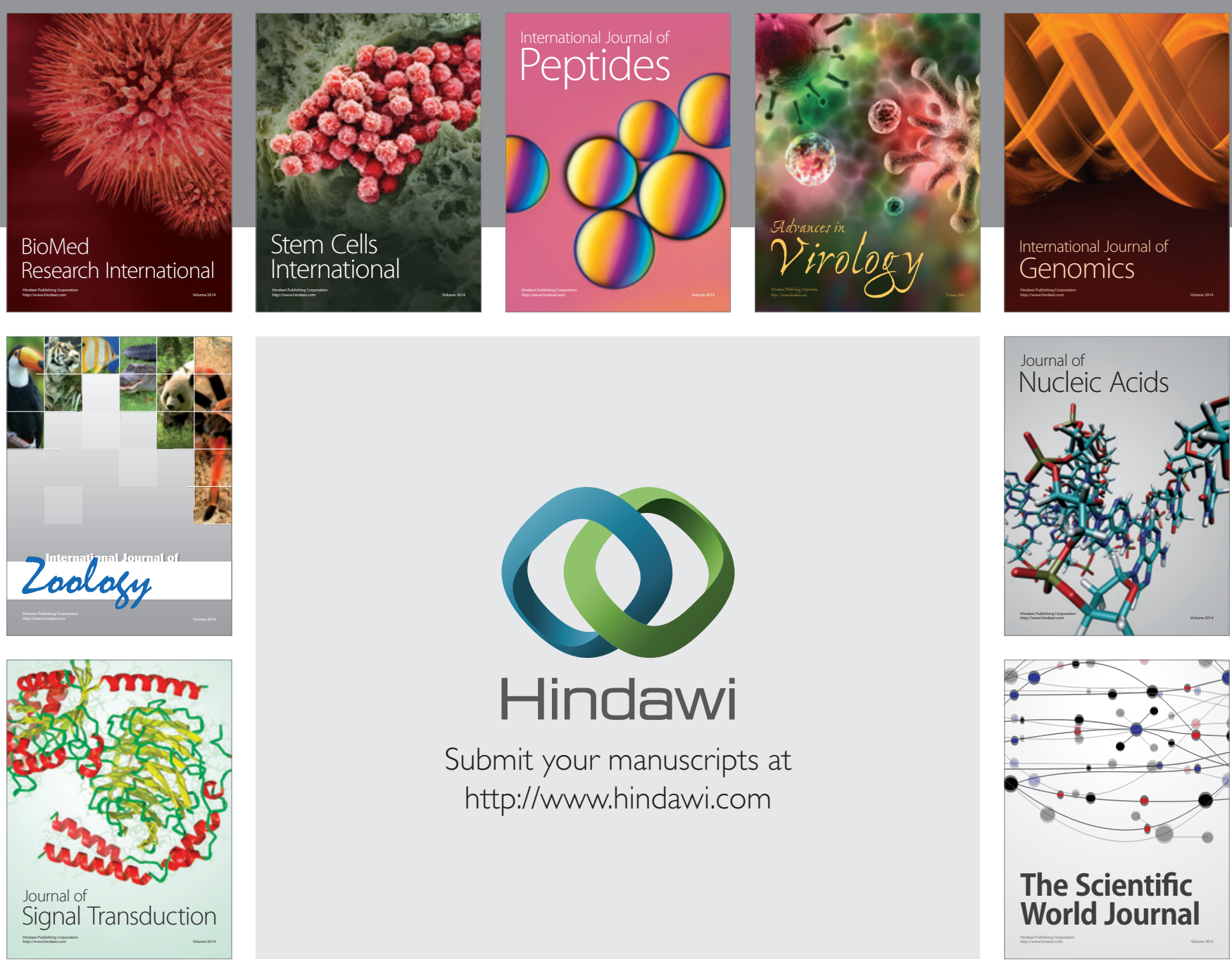

Submit your manuscripts at

http://www.hindawi.com
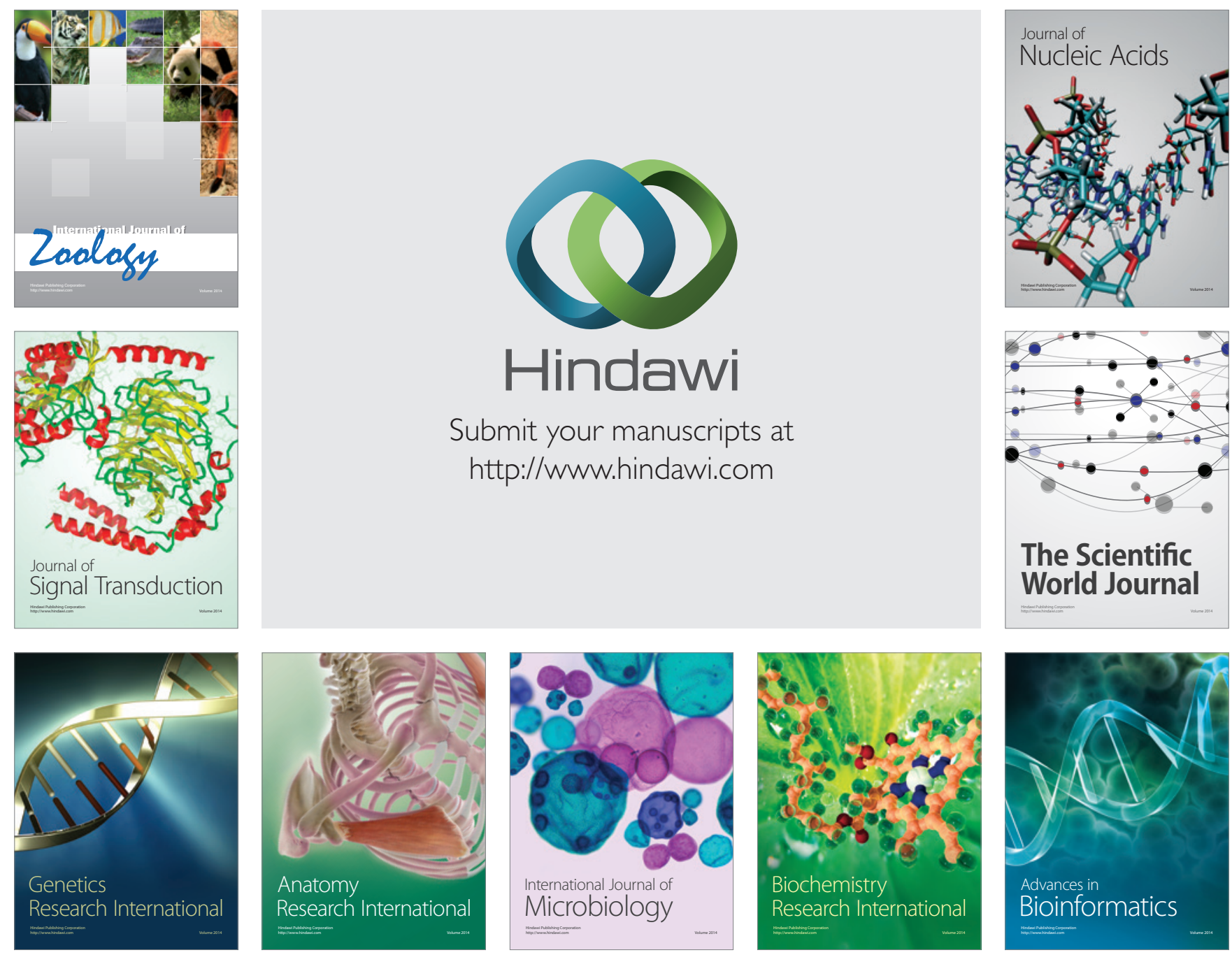

The Scientific World Journal
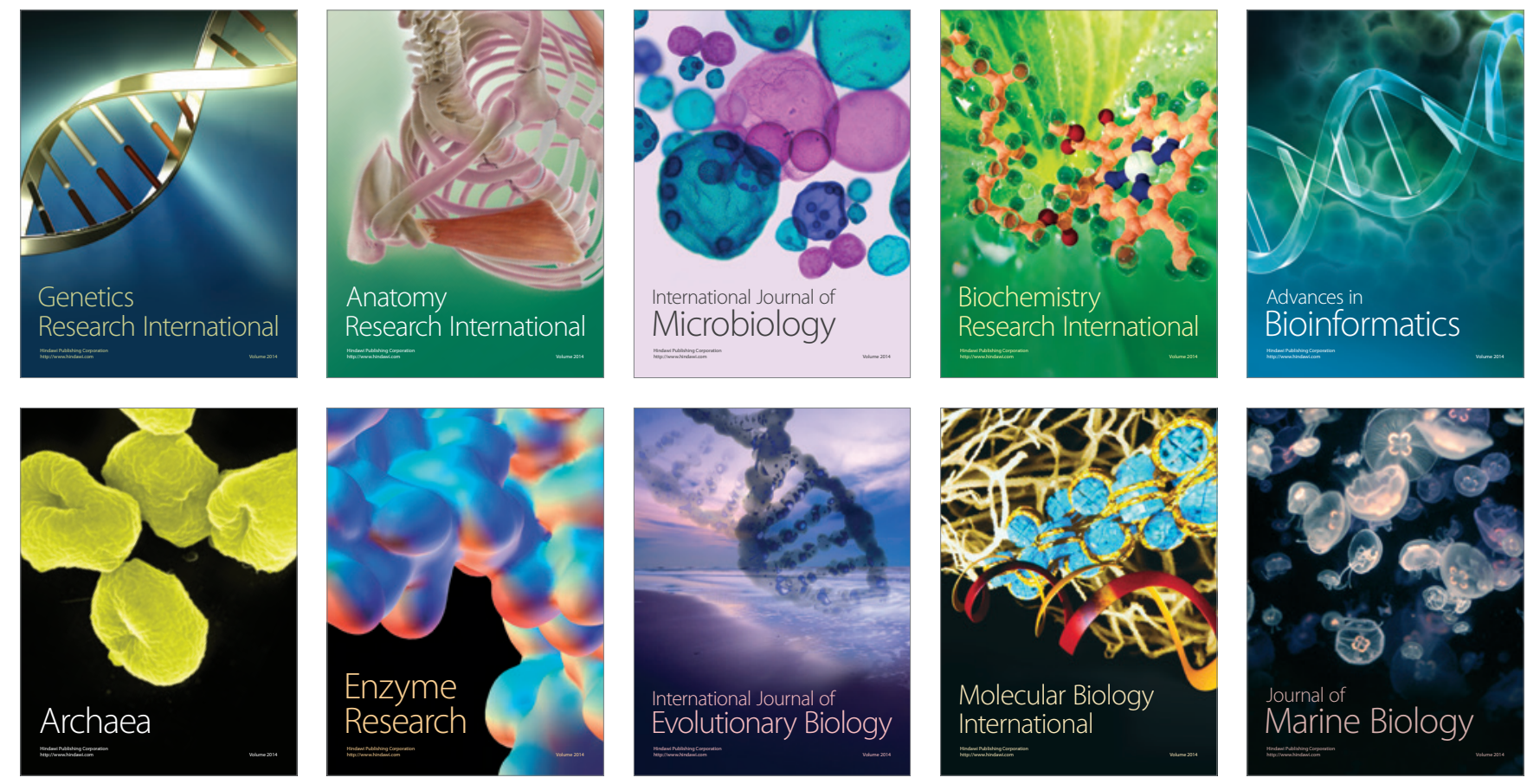